\title{
RELACJE POLSKI Z EUROPĄ ŚRODKOWO-WSCHODNIĄ - CZECHOSŁOWACJĄ (CZECHAMI, SŁOWACJĄ), RUMUNIĄ, WĘGRAMI - W XX I XXI WIEKU ORAZ ICH UWARUNKOWANIA WEWNĘTRZNE I MIĘDZYNARODOWE PRÓBA PODSUMOWANIA
}

Na przełomie XIX i XX w. relacje pomiędzy Polakami a sąsiednimi narodami regionu Europy Środkowo-Wschodniej - Czechami, Słowakami, Węgrami i Rumunami - zamieszkującymi na obszarze wyznaczonym od północy łańcuchem Karpat, od wschodu Morzem Czarnym, zaś od południa i zachodu dorzeczem Dunaju, uwarunkowane były dwoma wspólnymi tym nacjom, a zarazem sprzecznymi dążeniami, uwidoczniającymi się wśród ich elit politycznych. Stanowily je: z jednej strony formułowanie postulatów maksymalistycznych, zatem żądanie pełnej suwerenności i zgodnych z narodowymi ambicjami granic własnego, niepodległego państwa, implikujące traktowanie sąsiadów jako sprzymierzeńców $\mathrm{w}$ walce $\mathrm{z}$ hegemonią dynastii Habsburgów na wspomnianym obszarze; z drugiej - ograniczone i jak się wówczas zdawało jedynie realistyczne, pragmatyczne tendencje do uzyskania jak najlepszej pozycji, uprzywilejowanego stanowiska $w$ ramach liberalnej austro-węgierskiej monarchii, co skutkowało traktowaniem sąsiadów jako rywali w staraniach o uznanie tych roszczeń przez Wiedeń.

Węgry znalazły się pod władzą Habsburgów już na przełomie XVII i XVIII stulecia w konsekwencji wycofania się z obszarów Europy Środkowo-Wschodniej Turcji - pokonanej pod Wiedniem w 1683 r. i upokorzonej pokojem w Karłowicach z 1699 r. Ich status w granicach austriackiego państwa uległ istotnemu przekształceniu - od jednej z prowincji na początku XIX w., po uzyskanie pozycji równorzędnego Austriakom narodu współgospodarza 
w zreformowanej po klęsce w wojnie z Prusami w 1866 r. dualistycznej monarchii Habsburgów.

Z kolei wśród Czechów - poddanych Habsburgów jeszcze od XVI stulecia - w drugiej połowie XIX w. nasiliło się poczucie odrębnej tożsamości etnicznej i prężnie rozwijała się kultura narodowa. Pozostawali oni przy tym pod wplywem idei czechosłowakizmu, głoszącej istnienie jednego narodu czechosłowackiego, w którego skład wchodzić mieli obok nich również Słowacy.

Ci ostatni byli wówczas podatni na treści zawarte we wspomnianej koncepcji, obawiając się przede wszystkim madziaryzacji, a ideę budowania wspólnoty z bliskim kulturowo narodem czeskim traktując jako naturalną i skuteczną obronę przed wynarodowieniem przez Madziarów. Groźba ta była całkiem realna - ziemie Słowaków stanowiły część Węgier, nie posiadając choćby przywileju autonomii - nawet po reformie monarchii Habsburgów z 1867 r. Perspektywicznym celem ówczesnych politycznych i kulturalnych elit słowackich było przy tym utworzenie w granicach Austro-Węgier nowej jakości - federacji Słowian, obejmującej zresztą nie tylko Czechów i Słowaków, ale m.in. także Rusinów. Miała ona stanowić trzeci - obok austriackiego (niemieckiego) i węgierskiego - komponent habsburskiej domeny.

Autonomią w austriackiej części monarchii Habsburgów cieszyła się po 1867 r. Galicja. Politycznie, gospodarczo i kulturowo dominowali w niej Polacy, z którymi o pozycję we wschodniej części prowincji rywalizowali krzepnący jako odrębna wspólnota narodowa Ukraińcy (Rusini). Polskie elity polityczne, wśród których pierwszoplanową rolę odgrywali krakowscy i lwowscy konserwatyści, już po wybuchu I wojny światowej popierały oficjalnie ideę przeksztalcenia Austro-Węgier w monarchię trialistyczną, której trzeci podmiot polityczny stanowić mieli Polacy (po włączeniu w granice monarchii Habsburgów dawnego Królestwa Polskiego i jego połączeniu z Galicją) $)^{1}$.

Odmienne cele Węgrów (obawiających się osłabienia własnej, wyjątkowej pozycji $\mathrm{w}$ dwuczłonowym habsburskim imperium po realizacji planów Czechów i Słowaków z jednej, a Polaków z drugiej strony), elit czeskich i słowackich (pozostających w konflikcie z Madziarami, ale dystansujących się także od idei głoszonych przez Polaków w Galicji), wreszcie polityków galicyjskich (walczących o realizację koncepcji trializmu z niechętnymi jej Węgrami, choć dalekich również od entuzjazmu wobec haseł czechosłowakizmu), decydowały o występowaniu napięć i kontrowersji pomiędzy narodami, zamieszkującymi w granicach Austro-Węgier - zarówno przed wybuchem Wielkiej Wojny, jak i w jej trakcie.

${ }^{1}$ Zob. np.: J. Lewandowski (1986): Królestwo Polskie wobec Austro-Wegier 1914-1918, Warszawa. 
Należy podkreślić, że w tym okresie wśród najbardziej znaczących politycznych elit polskich, węgierskich, czeskich i słowackich mniejszą rolę odgrywały środowiska formułujące postulat całkowitej suwerenności narodowej i rozbicia monarchii Habsburgów, który mógłby stać się płaszczyzną wypracowania przez nie wzajemnego porozumienia i zainicjowania politycznej współpracy. Wypada jednocześnie zauważyć, że realizacja hasła pełnej niepodległości oznaczała nie tylko potencjalną perspektywę współdziałania Polaków z Węgrami, Czechami i Słowakami w dziele likwidacji hegemonii habsburskiej, ale także wystąpienia w przyszłości sporów granicznych pomiędzy wymienionymi nacjami, dążącymi do budowy odrębnych, suwerennych państw.

Tymczasem Rumunia na przełomie wieków, w przededniu I wojny światowej, była już niepodległym państwem. U schyłku XIX stulecia uwolniła się od tureckiej dominacji i stała się suwerennym królestwem, a w Wielkiej Wojnie poparła politycznie i militarnie Ententę. Krok ten był wynikiem traktowania przez Bukareszt Austro-Węgier jako monarchii zagrażającej jego pozycji w regionie. Rumunów dzielił również z Madziarami spór o terytorialną przynależność Siedmiogrodu. Konflikty rysujące się pomiędzy narodami państwa austro-węgierskiego (szerzej - zamieszkującymi Europę Środkowo-Wschodnią) źle wróżyły stabilizacji regionu u schyłku Wielkiej Wojny, kiedy to realnych kształtów nabrały perspektywy upadku dynastii Habsburgów i rozpadu ich monarchii.

\section{W labiryncie sprzecznych interesów}

Klęska państw centralnych w I wojnie światowej jesienią 1918 r. i idąca w ślad za nią erozja państwa austro-węgierskiego skutkowały powołaniem do życia niepodległej Czechosłowacji (28 października 1918 r.), w której granicach znalazły się Czechy, Morawy, węgierska dotąd Słowacja i Ruś Zakarpacka; samodzielnego państwa Madziarów (31 października 1918 r.) oraz zwiększeniem znaczenia Rumunii w regionie - zarówno ze względu na zniknięcie z mapy Europy jej wielkiego sąsiada, jak i perspektywę powiększenia jego kosztem terytorium państwa rumuńskiego (o węgierski Siedmiogród i austriacką Bukowinę).

Dnia 1 grudnia 1918 r. proklamowana została tzw. Wielka Rumunia. Ponadto korzystając z chaosu panującego w Rosji - ogarniętej rewolucyjnym zamętem i wojną domową - Bukareszt zaanektował Besarabię, którą dawne Hospodarstwo Mołdawskie (poprzednik Rumunii) utraciło jeszcze w początkach XIX w. na rzecz ówczesnego imperium Romanowów. Wzrost strategicznej roli Bukaresztu wynikał również z bolszewickiego puczu w Rosji, który uczynił z Rumunii państwo frontowe, ważny element tzw. kordonu sanitarnego, chroniącego Europę przed komunizmem i ewentualną sowiecką agresją. 
Odradzająca się równocześnie do suwerennego istnienia II Rzeczpospolita stanęła przed wyzwaniem nawiązania dobrych relacji z nowymi sąsiadami, organizującymi własne państwa na południe od terytoriów polskich. Było to zadanie trudne, zważywszy nie tylko na terytorialny, zbrojny zatarg Polski z Czechosłowacją o Śląsk Cieszyński, ale także na napięcia pomiędzy Pragą i Budapesztem (wynikające $\mathrm{z}$ wcielenia do państwa czechosłowackiego obszarów Słowacji zamieszkiwanych przez liczną mniejszość węgierską) oraz Budapesztem i Bukaresztem (spowodowane apetytami Rumunów na madziarski Siedmiogród).

W przypadku Węgier rozwój relacji został również zablokowany w wyniku komunistycznej rewolty, jaka ogarnęla ten kraj wiosną 1919 r. Komuniści i socjaldemokraci, którzy przejęli wówczas władzę w Budapeszcie, ogłosili powstanie Węgierskiej Republiki Rad. Na czele tej nowej, komunistycznej dyktatury w sercu Europy, posługującej się krwawym terrorem wobec własnych obywateli, stanął Béla Kun. Została ona obalona dopiero po ponad czterech miesiącach w wyniku ofensywy wojsk, dowodzonych przez Miklósa Horthy’ego, byłego admirała floty austro-węgierskiej z lat Wielkiej Wojny oraz rumuńskich i czechosłowackich oddziałów interwencyjnych. Pogromca węgierskich komunistów został głównodowodzącym węgierskich sił zbrojnych, a następnie regentem Królestwa Węgier, wprowadzając nad Dunajem konserwatywną dyktaturę.

Równocześnie porozumienie Warszawy z Budapesztem utrudniał odmienny stosunek obydwu stolic do traktatów pokojowych, podpisanych po zakończeniu I wojny światowej i ładu wersalskiego. O ile Polskę - podobnie zresztą, jak Czechosłowację i Rumunię, uznać należy za beneficjentów powojennych ustaleń, o tyle Węgry zostały przez państwa zwycięskie uznane za pozostałość Austro-Węgier, a zarazem jeden z podmiotów politycznych i wojskowych bloku państw centralnych. W wyniku podpisanego z nimi w $1920 \mathrm{r}$. traktatu pokojowego $\mathrm{w}$ Trianon obciążono je reparacjami wojennymi, nakazano zmniejszenie liczebności armii węgierskiej do 32 tysięcy i wprowadzono zakaz obowiązkowej służby wojskowej. Ponadto utracily one blisko $70 \%$ swego przedwojennego terytorium - m.in. Słowację, Zakarpacie, Siedmiogród, Wojwodinę i Chorwację - oraz dostęp do morza. W obliczu wspomnianych rozwiązań, narzuconych Madziarom, powszechne było wśród nich poczucie krzywdy i chęć rewizji traktatu $\mathrm{z}$ Trianon.

Wspomniane nastawienie Węgier do powojennych ustaleń pokojowych komplikowało plany Warszawy prowadzenia polityki zagranicznej, obliczonej na ustanowienie bliskich relacji z państwami regionu. Obawa przed perspektywą rewizji granic, postulowaną przez Budapeszt, skłoniła beneficjentów podziału przedwojennych Węgier - Czechosłowację, Jugosławię i Rumunię - do zawiązania na początku lat dwudziestych Małej Ententy (choć formalnie pakt organizacyjny został podpisany dopiero w 1934 r.). Wobec nieufności i niechęci 
pomiędzy Węgrami i sygnatariuszami Małej Ententy, postulowane przez polską dyplomację ułożenie dobrych stosunków z południowymi sąsiadami w regionie i ich kultywowanie, stawało się niezwykle trudne ${ }^{2}$.

$\mathrm{W}$ tej skomplikowanej sytuacji zdecydowanie najbliższe relacje łączyły Warszawę z Budapesztem i Bukaresztem. W pierwszym przypadku były one tyleż rezultatem tradycyjnych, historycznych sympatii, co wspólnej świadomości zagrożenia komunizmem i agresywną polityką czerwonego Kremla. Wlatach wojny polsko-sowieckiej Węgry zaoferowały Rzeczypospolitej pomoc militarną w postaci wsparcia polskiej armii jednostkami kawalerii oraz przesyłając nieodpłatnie własnym taborem kolejowym duże dostawy sprzętu wojskowego, broni i amunicji. Obydwa państwa łączyła również krytyka polityki wewnętrznej i zagranicznej Pragi - tolerancyjnej dla działalności komunistów w państwie czechosłowackim, ograniczającej prawa polskiej i węgierskiej mniejszości narodowej oraz nastawionej na poszukiwanie zbliżenia z Moskwą.

Obawa przed zagrożeniem ze strony bolszewickiej Rosji była również determinantą ustanowienia przyjaznych i sojuszniczych relacji polsko-rumuńskich. Ich podstawą stał się zawarty w marcu $1921 \mathrm{r}$. układ o wzajemnej pomocy w razie agresji ze strony państwa sowieckiego. Potwierdziły je zaś kolejne dwa traktaty przymierza z marca $1926 \mathrm{r}$. i stycznia $1931 \mathrm{r}$. Warto przypomnieć, iż przesłanie Polsce węgierskiej pomocy wojskowej jeszcze w latach wojny polsko-sowieckiej stało się możliwe dzięki zgodzie Bukaresztu na jej transport przez terytorium Rumunii. Dzięki inicjatywie Warszawy południowy sąsiad, a zarazem sojusznik Rzeczypospolitej, stał się również sygnatariuszem protokołu Litwinowa z $1929 \mathrm{r}$. Kiedy Związek Sowiecki zaproponował Polsce podpisanie protokołu dwustronnego, według którego antywojenny pakt Brianda-Kellogga, odrzucający wojnę jako instrument polityki, nabrałby dla Moskwy i Warszawy ${ }^{3}$ mocy natychmiast po jego ratyfikacji przez obie stolice, Rzeczpospolita uwarunkowała jego podpisanie

${ }^{2}$ Wypada zauważyć, iż każde z państw Małej Ententy miało sąsiada, przeciw któremu pomoc obu partnerów byłaby pożądana, jednak takiej pomocy układy wzajemne nie przewidywały. Jugosławia obawiała się Włoch, Czechosłowacja - Niemiec, a Rumunia - państwa sowieckiego. Równocześnie z każdym z tych sąsiadów i ewentualnych agresorów przeciw jednemu z państw Małej Ententy, obaj jego sojusznicy nie pozostawali w konflikcie: Czechosłowacja i Rumunia z Włochami, Jugosławia i Rumunia z Niemcami, a Czechosłowacja i Jugosławia z Moskwą.

${ }^{3}$ Związek Sowiecki (Związek Socjalistycznych Republik Sowieckich) został utworzony w 1922 r. na mocy układu, podpisanego przez rządzone przez bolszewików, lecz formalnie niepodległe: Rosyjską Federacyjną Socjalistyczną Republikę Sowiecką, Ukraińską Socjalistyczną Republikę Sowiecką, Białoruską Socjalistyczną Republikę Sowiecką i Zakaukaską Federacyjną Socjalistyczną Republikę Sowiecką. 
od poszerzenia listy sygnatariuszy m.in. o Rumunię. Polska rozwijała również współpracę gospodarczą i handlową z państwem Madziarów i Rumunią ${ }^{4}$.

$\mathrm{Na}$ tym tle stosunki polsko-czechosłowackie prezentowały się zdecydowanie najgorzej. Obydwa państwa dzielił nie tylko stosunek do komunizmu i państwa sowieckiego, zatarg graniczny o Śląsk Cieszyński, traktowanie mniejszości polskiej w Czechosłowacji i rywalizacja o miano lidera Europy Środkowo-Wschodniej, a zarazem najważniejszego sojusznika mocarstw zachodnich w regionie, ale także wzajemne przekonanie o słabości sąsiada (Warszawa upatrywała jej w wielonarodowym charakterze państwa czechosłowackiego, Praga zaś - w równoczesnym skonfliktowaniu Rzeczypospolitej z Niemcami i państwem sowieckim). W świetle przywołanych okoliczności nie może dziwić to, iż formułowane w środowisku czeskiej elity politycznej jeszcze u schyłku I wojny światowej plany unii polsko-czechosłowackiej szybko zostały odłożone do lamusas.

Niechęć Czechosłowacji do północnego sąsiada dała o sobie znać, kiedy podczas wojny polsko-sowieckiej odmówiła ona prośbie o umożliwienie transportu węgierskiego wojska, sprzętu wojennego, broni i amunicji, mających wspomóc wysiłek zbrojny Rzeczypospolitej. Polacy wspierali również Słowaków z czasem coraz wyraźniej działających w kierunku uzyskania niezależności, aż do odrębnego państwa. Czesi odpłacali się wspieraniem nielegalnej irredenty ukraińskiej w II Rzeczypospolitej.

Tym niemniej warto zauważyć, iż później to polska dyplomacja podejmowała kroki, mające na celu normalizację stosunków, a w perspektywie zbliżenie z Czechosłowacją. W 1921 r. została podpisana konwencja handlowa, a następnie umowa polityczna, będąca wynikiem pojednawczego stanowiska Warszawy, która przechodziła właściwie do porządku dziennego nad konfliktem cieszyńskim. Celem tych porozumień było zapewnienie neutralności Pragi na wypadek konfliktu z państwem trzecim. Powyższy pakt zaręczał wzajemną integralność granicom. Miało to stanowić fundament przyszłych dobrosąsiedzkich stosunków, współpracy politycznej i gospodarczej. Układ został dobrze przyjęty w Paryżu - najważniejszym partnerze obu państw na arenie międzynarodowej. Jednak nie został ratyfikowany przez polski parlament, który - podobnie jak większość środowisk politycznych Rzeczypospolitej - skrytykował go jako rezultat zbyt daleko idących, jednostronnych ustępstw rodzimej dyplomacji.

Polska w latach 1926-1927 usiłowała także nawiązać kontakty z Czechosłowacją w dziedzinie wojskowej. Mimo, że techniczna współpraca sztabowa

${ }^{4} \mathrm{O}$ stosunkach polsko-rumuńskich $\mathrm{w}$ okresie międzywojnia w: H. Walczak (2008): Sojusz z Rumunia w polskiej polityce zagranicznej w latach 1918-1931, Szczecin.

5 Patrz np.: M.K. Kamiński (2001): Konflikt polsko-czeski 1918-1921, Warszawa. 
trwała do 1935, sama konwencja wojskowa była nie do przyjęcia dla Czechów. W 1935 r. nastąpiły silne rozdźwięki dyplomatyczne w stosunkach polsko-czechosłowackich, m.in. po podpisaniu przez Pragę paktu sojuszniczego z ZSRS ${ }^{6}$.

W polsko-czechosłowackich relacjach dramatyczny okazał się schyłek lat trzydziestych minionego stulecia. W rezultacie wysunięcia przez Berlin postulatów terytorialnych wobec Pragi, które zyskały na konferencji w Monachium we wrześniu 1938 r. akceptację Wielkiej Brytanii, Francji i Włoch, od Czechosłowacji zostały oderwane Sudety, włączone następnie w granice III Rzeszy. W sytuacji osłabienia niechętnego Polsce południowego sąsiada z żądaniami ustępstw terytorialnych wystąpiła również m.in. Warszawa, domagając się zwrotu przez Czechów, zajętego przez nich zbrojnie w 1919 r. Śląska Cieszyńskiego (Zaolzia) ${ }^{7}$. Upokorzone na arenie międzynarodowej i ubezwłasnowolnione dyktatem monachijskim, okaleczone państwo czechosłowackie przetrwało niecałe pół roku. Przekształcone początkowo w federację Czech, Słowacji i Ukrainy Karpackiej, w marcu 1939 r. uległo podziałowi na Protektorat Czech i Moraw wcielony do Niemiec, uzależnioną od nich Słowację i efemerydę - Karpato-Ukrainę, włączoną następnie w granice Węgier.

Godzi się dodać, iż postępująca od jesieni 1938 r. erozja czechosłowackiej państwowości uaktywniła słowackie elity polityczne, próbujące $\mathrm{w}$ tych dramatycznych okolicznościach reaktywować ideę konfederacji pomiędzy sąsiadami - tym razem w postaci trójpodmiotowej unii polsko-czesko-słowackiej. Myśl ta nie wykroczyła jednak poza poziom dość mglistych założeń.

Aktywność dyplomatyczną Rzeczypospolitej w regionie określały w latach trzydziestych XX w. - obok prób wypracowania i pielęgnowania korzystnych relacji z Węgrami i Rumunią oraz unormowania stosunków z Czechosłowacją - również wysiłki, zmierzające do realizacji perspektywicznej, w założeniu docelowej idei Międzymorza, określanego też mianem Trzeciej Europy.

Ideę włączenia państw Europy Środkowo-Wschodniej w ściśle określony organizm federacyjny formułowal już w pierwszej połowie lat dwudziestych minionego stulecia generał Władysław Sikorski, ówczesny premier II Rzeczypospolitej. Generał Sikorski postulował zbudowanie federacji, wiążącej kraje

${ }^{6}$ Por.: M.K. Kamiński (2014): Szkice z dziejów Polski i Czechosłowacji w latach trzydziestych XX wieku, Warszawa; J. Kozeński (1964): Czechosłowacja w polskiej polityce zagranicznej w latach 1932-1938, Poznań; Stosunki polsko-czesko-słowackie w latach 1918-1945 (1992): red. E. Orlof, Rzeszów; S. Pilarski (2017): Między obojętnością a niechęcią. Pitsudczycy wobec Czechosłowacji w latach 1926-1939, Łódź.

7 Wobec republiki Czechów i Słowaków zdecydowały się wystąpić też Polska i Węgry. Polska zajęła Zaolzie, a Węgry ( $w$ wyniku tzw. arbitrażu wiedeńskiego) południową Słowację i Ruś Zakarpacką. 
od Bałtyku po Bałkany, która mogła stać się potęgą - nie tylko regionalną, lecz w skali całego kontynentu. Idea ta zakładała ścisłą współpracę polityczną i ekonomiczną państw Europy Środkowo-Wschodniej, co miało stanowić gwarancję jej trwałości. Federacja miała obejmować m.in. Czechosłowację, Węgry, Rumunię, państwa bloku bałtyckiego, a także bałkańskie: Jugosławię i Grecję. Jej filarem miała być Rzeczpospolita.

Federację państw nadbałtyckich i bałkańskich z Polską rozważał jednak przede wszystkim już od narodzin drugiej niepodległości Józef Piłsudski - Naczelnik Państwa, a po 1926 r. jego faktyczny dyktator. Widział w niej miejsce - obok Rzeczypospolitej - dla Czechosłowacji, Węgier, Rumunii, Bułgarii, Jugosławii i Grecji, jak również Skandynawii i republik nadbałtyckich. Kiedy Marszałek zmarł w $1935 \mathrm{r}$. koncepcję tę podjął ówczesny polski minister spraw zagranicznych, Józef Beck.

W latach trzydziestych zakładała ona w najbardziej ambitnej, maksymalistycznej wersji utworzenie z inicjatywy Warszawy bloku polityczno-gospodarczo-wojskowego pomiędzy Niemcami i Związkiem Sowieckim, zbudowanego z państw skandynawskich, republik nadbałtyckich, państw dorzecza Dunaju i bałkańskich. Blok ten miał stabilizować region, zapewniając zarazem bezpieczeństwo i rozwój gospodarczy jego członkom.

Ambitny, lecz jak się okazało mało realistyczny projekt, pozostał jedynie w sferze planów wobec zbyt dużej rozbieżności interesów niedoszłych partnerów Rzeczypospolitej oraz nie dość silnej pozycji państwa polskiego jako podmiotu międzynarodowej polityki. Region Europy Środkowo-Wschodniej, w którym sąsiadowały ze sobą państwa o bardzo rozbieżnych - jak się okazało - interesach, padł ofiarą zaborczości III Rzeszy i Związku Sowieckiego.

\section{Wojenne rozstaje}

Pomimo przegranej przez Rzeczpospolitą wojny obronnej we wrześniu 1939 r., podziału i okupacji jej ziem przez Niemcy i Związek Sowiecki (od 1941 r. wyłącznie przez III Rzeszę), wobec decyzji władz polskich o niepodpisywaniu aktu kapitulacji i prowadzeniu nadal walki, instytucje polskiej państwowości (prezydent, rząd, Rada Narodowa, polskie siły zbrojne z naczelnym dowództwem) rozpoczęły działalność na emigracji. Ich siedzibą stała się najpierw sojusznicza Francja, a po jej upadku - w wyniku niemieckiej agresji 1940 r. - drugi aliant Rzeczypospolitej, czyli Wielka Brytania.

Obok kontynuacji wojny $\mathrm{z}$ hitlerowskimi Niemcami, zajęcia stanowiska wobec drugiego najeźdźcy - ZSRS - i dbałości o relacje ze sprzymierzonym Paryżem i Londynem, istotnym wyzwaniem, stojącym przed polskimi 
władzami na uchodźstwie, było nawiązanie stosunków z utworzonym w Londynie emigracyjnym rządem czechosłowackim oraz wypracowanie koncepcji przyszłego ładu międzynarodowego, mającego zapanować po zakończeniu wojny w Europie Środkowo-Wschodniej.

Wątkiem dominującym $\mathrm{w}$ relacjach polsko-czechosłowackich $\mathrm{w}$ pierwszych latach II wojny światowej były próby stworzenia fundamentów dla powojennej federacji Warszawy i Pragi. Już we wrześniu 1940 r. doszło do rozmów pomiędzy premierami obydwu państw - Władysławem Sikorskim i Edvardem Benešem. Ich celem było sprecyzowanie i zbliżenie stanowisk stron wobec planu federacji. Było to o tyle istotne, że polski rząd uznawal prawo Słowaków do własnego państwa, a miejsce w federacji rezerwował jedynie dla Czechów, co spotykało się ze zrozumiałym poniekąd sprzeciwem polityków znad Wełtawy.

Odmienny pogląd na przyszłość charakteru relacji czesko-słowackich nie był jedyną przeszkodą na drodze do osiągnięcia federacyjnego kompromisu. Kolejną stanowily przeciwstawne wręcz oceny Związku Sowieckiego, formułowane przez polityków polskich i czeskich. Niezależnie od ewentualnego powodzenia planów federacyjnych, E. Beneš widział w ZSRS państwo, które będzie w przyszłości odgrywało pierwszoplanową rolę na wschodzie Starego Kontynentu i dążył do bliskich z nim relacji. Tymczasem do $1941 \mathrm{r}$. Kreml pozostawał dla rządu polskiego agresorem, a i po niemieckim ataku na państwo sowieckie oraz układzie Sikorski-Majski pozostawał sojusznikiem kontrowersyjnym, którego dzieliły z Rzecząpospolitą bardzo istotne różnice - z oceną agresji 17 września 1939 r. i wizją przyszłej wspólnej granicy włącznie.

W trakcie polsko-czechosłowackich negocjacji politycy znad Wettawy wystąpili z propozycjami, które jeszcze bardziej komplikowały sprawę ewentualnego zbliżenia stanowisk. Nie forsowali bowiem zawiązania trwałej federacji, a jedynie luźnej konfederacji. Przez stronę polską było to interpretowane jako zapowiedź tymczasowego, koniunkturalnego charakteru proponowanego związku. Ostatecznie E. Beneš przedstawił w listopadzie 1940 r. memorandum, w którym postulował prowadzenie dalszych prac nad zjednoczeniem, wzajemne informowanie się negocjujących rządów o istotnych wydarzeniach dyplomatycznych i wojskowych, doprowadzenie do określenia stosunku polsko-czechosłowackiego aliansu do Europy Zachodniej oraz ustalenie zasad jego wspólnej polityki wobec ZSRS. W. Sikorski odpowiedział na dokument już na początku grudnia 1940 r. Uznawał on, że stosunki sąsiedzkie pomiędzy konfederacją a Związkiem Sowieckim nie powinny opierać się na nadmiernej pojednawczości i poświęcaniu interesów Warszawy i Pragi na rzecz wschodniego sąsiada. Podkreślał, że negocjujące strony winny jasno sformułować swoje podmiotowe stanowisko wobec Moskwy, stawiając ją przed wyborem nawiązania przyjaznych stosunków ze związkiem polsko-czechosłowackim lub koniecznością zetknięcia 
się z jego oporem wobec ewentualnych prób rozciągnięcia nad nim wpływów Kremla, czy wręcz skomunizowaniem.

Niezależnie od wspomnianych rozbieżności obie strony deklarowały, iż zamykają symbolicznie okres dawnych uraz i sporów. Wskazywały na wspólnotę podstawowych interesów oraz swą determinację, aby po zwycięskim zakończeniu wojny z III Rzeszą i jej sojusznikami, utworzyć jako państwa niepodległe i suwerenne ścisły związek polityczny i gospodarczy, który stałby się podstawą nowego porządku w Europie Środkowej i gwarancją jego trwałości.

W końcu 1940 r. prace nad przygotowaniem przyszłego związku państw uległy intensyfikacji. Do specjalnego komitetu koordynacyjnego zostali powołani ze strony polskiej m.in.: wicepremier oraz minister informacji i dokumentacji Stanisław Stroński; minister spraw zagranicznych August Zaleski, minister sprawiedliwości Marian Seyda i ambasador polski w Wielkiej Brytanii Edward Raczyński. Natomiast strona czechosłowacka wyznaczyła do udziału w komitecie ministra spraw zagranicznych Jana Masaryka, ministra spraw wewnętrznych Juraja Slavika i sekretarza stanu do spraw propagandy Huberta Ripkę. Komitet koordynacyjny rozpoczął wspólne studia, dotyczące przyszłej konfederacji. Podejmował prace bieżące w kwestiach: polityki zagranicznej, informacji, spraw wojskowych i kultury. Były one kontynuowane pomimo przejściowych perturbacji, wywołanych podpisaniem układu Sikorski-Majski i odejścia z rządu - w ramach protestu przeciwko zapisom tego układu - A. Zaleskiego i M. Seydy.

Ostatecznie przygotowany tzw. akt konstytucyjny polsko-czechosłowackiego związku prezentował plan przyszłych, wspólnych działań w sferze politycznej, społecznej i gospodarczej. Zawierał zasady utworzenia związku, ramy ustrojowe, kompetencje (wynikające z przejęcia części praw suwerennych obydwu państw), wspólne działania w dziedzinie polityki zagranicznej, gospodarczej, skarbowej, podatków, komunikacji, spraw żeglugi morskiej, zatrudnienia, ustawodawstwa socjalnego, wreszcie obrony związku. Natomiast głównym przedmiotem pozostawała sprawa państwowej przynależności Zaolzia. Politycy czechosłowaccy stali na stanowisku konieczności jego powrotu w granice Czechosłowacji, Polacy - utrzymania tego obszaru przy państwie polskim.

W 1942 r. przedstawiciele obydwu rządów podpisali wspólną deklarację o utworzeniu Rady Planowania Europy Środkowej i Wschodniej. Jej celem było przygotowanie odbudowy gospodarczej, społecznej i edukacyjnej w regionie. Polacy brali również pod uwagę włączenie w granice szerszej unii (swoistej federacji Europy Środkowo-Wschodniej) także innych państw regionu, co spotykało się jednak ze sceptycyzmem polityków czechosłowackich. Osią kontrowersji pozostawał również charakter przyszłego związku - o ile strona polska proponowała ukonstytuowanie państwa federacyjnego z jednolitą służbą dyplomatyczną oraz wojskiem, o tyle Czesi opowiadali się nadal za związkiem 
dwóch państw z zachowaniem odrębności instytucjonalno-politycznej i objęciem koordynacją jedynie polityki zagranicznej, gospodarczej i wojskowej.

Polsko-czechosłowackie prace nad stworzeniem federacyjnego, czy też konfederacyjnego, związku Rzeczypospolitej i Czechosłowacji nie wywołały entuzjazmu wśród zachodnich aliantów, zaniepokojonych samodzielnością polityków znad Wisły i Wełtawy, która mogła w przyszłości skutkować emancypacją regionu spod wpływów Londynu i Paryża, a przede wszystkim ochłodzić stosunki mocarstw zachodnich ze Związkiem Sowieckim, posiadającym plany własnej hegemonii na wschodzie przyszłej powojennej Europy. Kreml dał im wyraz w połowie 1942 r., oprotestowując projekt polsko-czechosłowackiego zbliżenia i nadania mu instytucjonalnego charakteru.

Wobec niechęci zachodnich aliantów Polski i Czechosłowacji i otwartego sprzeciwu Moskwy, projekty powojennego związku Warszawy i Pragi załamały się. Natomiast jesienią 1942 r. politycy czechosłowaccy zaproponowali zawarcie układu sojuszniczego z Polską na 20 lat. Współpraca obu rządów, związana z próbami przygotowania przyszłej unii państwowej, a później podpisania układu sojuszniczego Warszawy i Pragi zakończyła się z początkiem 1943 r., kiedy strona czechosłowacka otwarcie poinformowała Polaków, że z racji sprzeciwu Moskwy nie tylko wobec konfederacji polsko-czechosłowackiej, ale i układu sojuszniczego, nie widzi ona możliwości kontynuowania wspólnych prac. W powiązaniu z napiętą sytuacją pomiędzy Kremlem a rządem polskim po odkryciu grobów katyńskich i wystąpieniem Polaków do Międzynarodowego Czerwonego Krzyża o zbadanie okoliczności mordu na oficerach Wojska Polskiego, wreszcie po jednostronnym zerwaniu przez Kreml stosunków z władzami polskimi na uchodźstwie - w maju 1943 r. czechosłowaccy politycy poinformowali, że zawieszają prace dotyczące budowania związku państwowego, a nawet przygotowania układu sojuszniczego z Rzecząpospolitą ${ }^{8}$.

Relacje pomiędzy Polakami i Słowakami w okresie II wojny światowej naznaczone były dramatyczną niejednoznacznością. Z jednej strony, Słowacja wzięła udział w 1939 roku w ataku na Polskę jako sojusznik III Rzeszy. Po upadku Rzeczypospolitej jej południowy sąsiad powiększył też - nieznacznie - swoje terytorium o kilka polskich wsi na Spiszu i Orawie. Rząd słowacki

${ }^{8}$ Patrz np.: T. Kisielewski (1991): Federacja środkowo-europejska. Pertraktacje polsko-czechosłowackie 1939-1943, Warszawa; I. Kolendo (2015): Unia Polsko-Czechosłowacka. Projekt z lat 1940-1943. Ukochane dziecko premiera gen. Wtadystawa Sikorskiego, Łódź; M.K. Kamiński (2005): Eduard Beneš kontra gen. Władysław Sikorski. Polityka wtadz czechosłowackich na emigracji wobec rzadu polskiego na uchodźstwie 1939-1943, Warszawa. 
pozostawał również sojusznikiem Hitlera przez lata II wojny światowej ${ }^{9}$ Z drugiej strony, wśród słowackich emigrantów - przeciwników aliansu z III Rzeszą - bardzo żywe były propolskie sympatie. Już w październiku 1939 r. w środowisku słowackich uchodźców poparciem cieszyły się koncepcje wprowadzenia w życie po wojnie planu zbiorowego bezpieczeństwa w Europie Środkowo-Wschodniej. Miał się on opierać na federacji złożonej z Polski, Czechosłowacji, Austrii, Węgier, Jugosławii, Rumunii i Bułgarii. Znamienne, iż w sferze relacji pomiędzy Rzecząpospolitą a Czechosłowacją koncepcje te były bliższe pomysłom polskim niż wysuwanym przez rząd czechosłowacki na obczyźnie - tak też interpretowali je polscy politycy i witali z satysfakcją.

Lata II wojny światowej były również okresem ciężkiej próby dla znakomitych od 1918 r. - zarówno na poziomie stosunków międzypaństwowych, jak i panujących pomiędzy samymi narodami - relacji polsko-węgierskich. Budapeszt przystąpił wszak do państw Osi i wraz z nimi brał udział w wojnie z koalicją antyhitlerowską, której członkiem była Polska. Jednak warto pamiętać, że w 1939 r. Węgry odmówiły III Rzeszy dokonania inwazji na Polskę z ich terytorium. Znamienne, że Budapeszt podkreślał przy tym w rozmowach z Niemcami istnienie niezwykle silnych propolskich sympatii nad Dunajem, argumentując, że pośrednie lub bezpośrednie wystąpienie przeciwko Rzeczypospolitej mogłoby wywołać niebezpieczne rozruchy w $\mathrm{kraju}^{10}$.

Po przegranej kampanii wrześniowej 1939 r. na Węgrzech bezpieczne schronienie znalazło ponad sto tysięcy polskich uchodźców. Pomimo presji Berlina Budapeszt zezwolił też jeszcze przez dwa miesiące na funkcjonowanie polskiego poselstwa. Dzięki determinacji jego pracowników, ale także milczącemu przyzwoleniu węgierskich władz, przez kilka miesięcy znad Dunaju przedostało się do sojuszniczej Francji i odbudowujących się na jej terytorium polskich sił zbrojnych, blisko 40 tysięcy żołnierzy i oficerów Wojska Polskiego, wszak wcześniej internowanych oficjalnie na Węgrzech.

Z kolei u schyłku II wojny światowej w czasie powstania warszawskiego węgierskie oddziały stacjonujące w okupowanej stolicy Polski znalazły się pod baczną obserwacją Niemców, którzy podejrzewali, że mogą one włączyć się do walki po stronie powstańców. Węgrzy często oferowali też żołnierzom Armii Krajowej (AK) broń, a cywilnej ludności - żywność.

9 Zob. np. w: Stosunki polsko-czesko-stowackie... ; A. Olejko (2012): Niedoszly sojusznik czy trzeci agresor? Wojskowo-polityczne aspekty trudnego sasiedztwa Polski i Stowacji 1918-1939, Kraków.

10 Więcej zob.: M. Koźmiński (1970): Polska i Węgry przed druga wojną światowa (październik 1938 - wrzesień 1939). Z dziejów dyplomacji i irredenty, Wrocław. 
Wreszcie nastąpily także tajne pertraktacje pomiędzy dowództwem powstania a oficerami węgierskimi, którzy zaproponowali przejście jednostek wojskowych Madziarów, znajdujących się na obszarze okupowanej Rzeczypospolitej na polską stronę oraz natychmiastowe, bezpośrednie militarne wsparcie Armii Krajowej, prowadzącej właśnie akcję Burza. W celu uzgodnienia współdziałania bezpośrednio z władzami państwa węgierskiego zaproponowano Komendzie Głównej AK przetransportowanie jej przedstawiciela do Budapesztu, a później do Londynu. Węgrzy zamierzali bowiem wykorzystać przyszłą wspólną z Polakami akcję zbrojną jako wstęp do otwartego przejścia na stronę koalicji antyhitlerowskiej i uzgodnić jego warunki z aliantami. Plan nie doszedł ostatecznie do skutku.

Po ataku niemieckim na Polskę w 1939 r. neutralność w obliczu zbrojnego konfliktu ogłosiła również Rumunia. Decyzja ta wynikała zarówno z kalkulacji politycznej Bukaresztu, jak i żywych sympatii do Polski i Polaków, panujących wśród Rumunów. Polskie władze, (prezydent Ignacy Mościcki, Naczelny Wódz Edward Śmigły-Rydz ze sztabem oraz rząd z premierem Felicjanem Sławojem Składkowskim), które przekroczyły granice z Rumunią, oczekując prawa przejścia przez terytorium sojuszniczego od $1921 \mathrm{r}$. państwa ${ }^{11}$, zostały jednak po naciskach niemieckich internowane.

Należy podkreślić, iż w latach II wojny światowej w środowisku polskiej emigracji - zarówno w kręgach rządowych, jak i polskich ugrupowań politycznych: Stronnictwa Narodowego, Stronnictwa Ludowego, Polskiej Partii Socjalistycznej, Stronnictwa Pracy, ale przede wszystkim w gronie piłsudczyków - widziano miejsce dla powojennych Węgier, jak i Rumunii (obok Czechosłowacji, republik nadbałtyckich, a nawet państw bałkańskich) w wielkiej federacji Europy Środkowo-Wschodniej. Jej powstanie traktowano przy tym jako czynnik stabilizujący region Trójmorza (pomiędzy Bałtykiem, Morzem Czarnym i Adriatykiem), tworzący przeciwwagę dla Związku Sowieckiego i Niemiec, jak też wnoszący istotny wkład w bezpieczeństwo i utrzymanie pokoju na całym kontynencie. Koncepcje te pojawiały się również w myśli i publicystyce politycznej Polskiego Państwa Podziemnego.

II wojna światowa była w dziejach Europy Środkowo-Wschodniej okresem wyjątkowo dramatycznym. Niektóre państwa regionu, na czele z najsilniejszą wśród nich Rzecząpospolitą, znalazły się pod okupacją niemiecką lub sowiecką. Inne - w obawie przed podobnym losem - zdecydowały się na nierównoprawny sojusz z III Rzeszą, godząc się w istocie na ograniczenie suwerenności na rzecz Berlina i stając się tym samym jego satelitami. W tych okolicznościach, niesprzyjających kultywowaniu dawnych relacji, koncepcje

${ }^{11}$ Rząd polski zdecydował się nie prosić Rumunii o pomoc militarną pomimo casus foederis wobec agresji ZSRS na Polskę. 
polityczne, jak i konkretne działania podejmowane przez polskie elity polityczne, dowodzily żywotności wśród nich idei budowania związku państw regionu, jaką głosiły w okresie międzywojnia.

Lata wojny okazały się też okresem, w którym dramatycznej próbie poddane zostały oddolne sympatie - bądź przynajmniej zdroworozsądkowe przekonanie o konieczności wspólnego poprawnego ułożenia relacji w powojennej przyszłości - żywe wśród nacji, zamieszkujących region.

\section{Bratnie demokracje ludowe}

Po zakończeniu II wojny światowej Polska wraz z innymi państwami Europy Środkowo-Wschodniej - również z na powrót zjednoczoną Czechosłowacją, Węgrami i Rumunią - oraz obszarem wschodnich Niemiec znalazła się w sferze wpływów Związku Sowieckiego. W państwach tych - oficjalnie niepodległych, lecz pozbawionych rzeczywistej suwerenności - u władzy znaleźli się lojalni wobec Moskwy lokalni komuniści, którzy zdobyli i utrzymywali władzę dzięki wsparciu Kremla, sowieckiego aparatu bezpieczeństwa i Armii Czerwonej (dysponującej bazami na terytorium zachodnich satelitów ZSRS). Zarówno nowa tzw. Polska Ludowa, jak i Czechosłowacja, Węgry, Rumunia, ale także Niemiecka Republika Demokratyczna (ukonstytuowana na terenie wschodnich Niemiec), Bułgaria i Albania, jako państwa tzw. bloku wschodniego, weszły w skład Układu Warszawskiego (UW - paktu polityczno-wojskowego utworzonego w 1955 r., któremu przewodził Związek Sowiecki) i Rady Wzajemnej Pomocy Gospodarczej (RWPG - porozumienia, dotyczącego wspólpracy i integracji ekonomicznej ZSRS i prosowieckich demokracji ludowych, powstałego pod egidą Kremla w 1949 r) .

Wzajemne stosunki Polskiej Rzeczypospolitej Ludowej (PRL), Czechosłowacji, Węgier i Rumunii w sferze politycznej, gospodarczej i wojskowej należy sytuować i rozpatrywać na trzech płaszczyznach. Pierwsza - polityczna i militarna - była związana z członkostwem wymienionych państw (i wynikających z niego zobowiązań) w sojuszu UW, który stanowił instrument wplywów Związku Sowieckiego na Starym Kontynencie. Drugą - gospodarczą - kształtowały relacje, będące rezultatem wejścia Warszawy, Pragi, Budapesztu i Bukaresztu do RWPG, której działania także w ostatecznym rozrachunku uzależnione były od akceptacji Moskwy.

Wreszcie trzecią płaszczyznę stanowiły oficjalne wzajemne relacje bilateralne Polski, Czechosłowacji, Węgier i Rumunii. Regulowały je traktaty, zawarte pomiędzy tymi państwami po zakończeniu II wojny światowej. W marcu 1947 r. został podpisany układ polsko-czechosłowacki, w czerwcu 1948 r. 
- polsko-węgierski, natomiast w styczniu 1949 r. - polsko-rumuński. Wszystkie te układy zostały zawarte na okres dwudziestu lat, z możliwością automatycznego przedłużenia ich ważności na dalsze pięcioletnie okresy, o ile żadna ze stron nie wypowiedziałaby układu na rok przed upływem ustalonego czasu. W praktyce wymienione państwa, w których władzę sprawowały partie komunistyczne, uzależnione od władz Związku Sowieckiego, nie korzystały z tej klauzuli, lecz automatycznie podpisywały nowe układy, zastępując nimi dotychczas obowiązujące.

Jak deklarowali sygnatariusze dwustronnych traktatów, podpisywanych przez PRL, miały one zapewnić bezpieczeństwo Polski Ludowej i jej sojuszników z bloku wschodniego oraz rozwój wzajemnych stosunków przyjaźni i współpracy, zmierzać do wzmocnienia socjalizmu w poszczególnych państwach i socjalistycznej wspólnoty na arenie międzynarodowej, wreszcie przyczyniać się do zwycięstwa w walce o pokój na świecie. W istocie były one komponentami systemu, jaki ukształtowany został w Europie Środkowo-Wschodniej z inicjatywy i pod dyktando Związku Sowieckiego, a zmierzał - również metodami zbrojnej interwencji - do destabilizacji tzw. Wolnego Świata ${ }^{12}$.

Niezależnie jednak od oficjalnej polityki zagranicznej prowadzonej przez PRL wobec jej sąsiadów w poddanym sowieckiej kontroli i komunistycznej dyktaturze regionie, polskie środowiska opozycyjne w kraju oraz instytucje polskiej państwowości i ugrupowania polityczne na emigracji próbowały odpowiedzieć na pytanie o środki, mogące doprowadzić do likwidacji komunizmu i sowieckiej hegemonii w kraju i całym bloku wschodnim, przyczyniając się do demokratyzacji Rzeczypospolitej, Czechosłowacji, Węgier i Rumunii i przywrócenia im suwerenności. Myśl polityczna polskich środowisk niepodległościowych, demokratycznych i antykomunistycznych wypracowała również koncepcje nowego międzynarodowego ladu w Europie Środkowo-Wschodniej, mającego zastąpić dominację Kremla i lokalne komunistyczne dyktatury.

Odpowiedź polskiej emigracji i krajowej opozycji na pytanie o sposób wyzwolenia Rzeczypospolitej i jej sąsiadów spod hegemonii Kremla i systemu komunistycznych dyktatur - będąca również wynikiem kontaktów i współpracy z uchodźcami i opozycjonistami czechosłowackimi, węgierskimi i rumuńskimi - ewoluowała w latach 1945-1989. Początkowo, bezpośrednio po zakończeniu II wojny światowej, wierzono w zbrojną interwencję Zachodu, której celem byłoby przywrócenie suwerenności i demokracji państwom zdominowanym

12 Por.: A. Szczepańska-Dudziak (2011): Warszawa-Praga 1948-1968. Od nakazanej przyjaźni do kryzysu, Szczecin; T. Kopyś (2015): Stosunki polsko-węgierskie w latach 1945-1970, Kraków; A. Sowińska-Krupka (1985): Stosunki polsko-rumuńskie 1945-1949, Warszawa. 
przez ZSRS. Przyszłość szybko zdemaskowała nierealistyczny charakter podobnego scenariusza, który został zastąpiony wizją - tym razem pozytywnie zweryfikowaną u schyłku XX w. - stopniowego bankructwa systemu komunistycznego i upadku Związku Sowieckiego w wyniku ich oparcia na nieracjonalnym systemie gospodarczym, presji ze strony Wolnego Świata, wreszcie - narastania i wybuchów społecznego niezadowolenia w państwach bloku wschodniego.

Zmianie ulegało również stanowisko polskich środowisk na obczyźnie i opozycyjnych w kraju w kwestii pożądanego przyszłego kształtu politycznego regionu. Początkowo reaktywowano i propagowano koncepcję utworzenia związku państw Europy Środkowo-Wschodniej, postulowaną przez dyplomację II Rzeczypospolitej, jak również emigracyjne polskie władze oraz instytucje i środowiska polityczne Polskiego Państwa Podziemnego w latach II wojny światowej.

W miarę postępującej integracji politycznej, wojskowej i gospodarczej Europy Zachodniej, opartej na ścisłym związku ze Stanami Zjednoczonymi i idei ładu transatlantyckiego, polscy uchodźcy i krajowi opozycjoniści, wspólnie z emigrantami i dysydentami czechosłowackimi, węgierskimi i rumuńskimi, zaczęli coraz wyraźniej opowiadać się za dołączeniem w przyszłości niepodległych i demokratycznych państw pomiędzy Bałtykiem, Morzem Czarnym i Adriatykiem do wspólnoty wojskowej i ekonomicznej Zachodu.

Należy także pamiętać o szczególnych relacjach, łączących po II wojnie światowej narody (społeczeństwa) polskie, czechosłowackie, węgierskie i rumuńskie. $\mathrm{Z}$ wielką sympatią Polaków spotkało się węgierskie powstanie 1956 r. i liberalne reformy praskiej wiosny w Czechosłowacji z 1968 r. Brutalne stłumienie niepodległościowego zrywu Węgrów przez Armię Czerwoną, a dwanaście lat później spacyfikowanie niepokornych Czechów i Słowaków w rezultacie zbrojnej interwencji państw Układu Warszawskiego (w której wzięły również udział wojska PRL) spowodował fale spontanicznej pomocy i współczucia dla sąsiednich narodów. Z drugiej strony Węgrzy i Czesi solidaryzowali się z wystąpieniami Polaków przeciwko komunistycznej dyktaturze, krwawo stłumionymi przez władze Ludowej Polski - poznańską rewoltą w czerwcu 1956 r., grudniowym wystąpieniem robotników na Wybrzeżu w 1970 r., czy ruchem Solidarności w latach 1980-1981 ${ }^{13}$.

Za symboliczne w tym kontekście uznać można Postanie do ludzi pracy Europy Wschodniej Niezależnego Samorządnego Związku Zawodowego Solidarność z września 1981 r. Delegaci zebrani w Gdańsku na I Zjeździe NSZZ

${ }_{13}$ J. Tischler (2001): I do szabli... Polska i Wegry. Punkty zwrotne $w$ dziejach obu narodów w latach 1956 oraz 1980-1981, Warszawa; Ł. Kamiński (red.) (2004): Wokót praskiej wiosny. Polska i Czechostowacja w 1968 roku, Warszawa. 
Solidarność przesłali robotnikom Czechosłowacji, Węgier, Rumunii, ale także Albanii, Bułgarii, Niemieckiej Republiki Demokratycznej i samego Związku Sowieckiego pozdrowienia, popierając ich $w$ walce o wolny ruch związkowy.

Dokument ten uznać można za rezultat, ale też podsumowanie tez głoszonych przez polską opozycję i emigrację po II wojnie światowej, a dotyczących wspólnoty losów Polaków, Czechów, Słowaków, Węgrów i Rumunów. Wprowadzenie stanu wojennego i pacyfikacja ruchu Solidarności, które nastąpiły zaledwie w trzy miesiące po wielkim gdańskim zjeździe, sprawiają, iż można go interpretować również jako swoisty testament polskich środowisk niepodległościowych, demokratycznych i antykomunistycznych po II wojnie światowej, odnoszący się do pożądanego kierunku rozwoju relacji z narodami czeskim słowackim, węgierskim i rumuńskim po upadku komunizmu i odzyskaniu suwerenności.

\section{W nowej Europie}

U zarania ostatniej dekady XX stulecia, w wyniku gospodarczego bankructwa systemu komunistycznego oraz idącego w ślad za nim ekonomicznego krachu i politycznego upadku Związku Sowieckiego (a później jego rozpadu), nastąpiła emancypacja dotychczasowych satelitów ZSRS spod wpływów Moskwy. Państwa regionu Europy Środkowo-Wschodniej odzyskały suwerenność na arenie międzynarodowej, czemu towarzyszyło zerwanie z totalitarnym ustrojem komunistycznym i modelem władzy sprawowanej w sposób dyktatorski przez lokalne partie komunistyczne, pozbawione wsparcia słabnącego Kremla. Nastąpiło też wycofanie jednostek Armii Czerwonej, stacjonujących po 1945 r. na terenie państw byłego bloku wschodniego. W 1991 r. rozwiązany został Układ Warszawski i Rada Wzajemnej Pomocy Gospodarczej ${ }^{14}$.

W Polsce w wyniku rozmów Okrągłego Stołu i czerwcowych wyborów parlamentarnych 1989 r. powstał pierwszy po zakończeniu II wojny światowej niekomunistyczny rząd. Rzeczpospolita stała się państwem demokratycznym, opartym na wolnorynkowym modelu gospodarczym. W wyniku tzw. Jesieni Ludów w 1989 r. system demokratyczny i liberalne reformy ekonomiczne wprowadzily też Czechosłowacja (która ponadto przekształciła się $\mathrm{w}$ federalną republikę, a w 1993 r. uległa pokojowemu podziałowi na niezależne państwa - Czechy i Słowację) oraz Węgry. Bardziej dramatyczny charakter miały przemiany w Rumunii, gdzie w grudniu 1989 r. została w wyniku krwawej rewolty

${ }^{14}$ Więcej w: Z. Gluza (2009): 1989. Koniec systemu. Polska, Węgry, NRD, Czechostowacja, Butgaria, Rumunia, Warszawa. 
obalona komunistyczna dyktatura Nicolae Ceaușescu, a on sam stracony na mocy wyroku samozwańczego sądu, powołanego i obsadzonego przez wojskowych, którzy wypowiedzieli reżimowi posłuszeństwo.

Nowa sytuacja geopolityczna wymagała od Warszawy nawiązania i wypracowania modelu relacji z Pragą (później również Bratysławą), Budapesztem i Bukaresztem z uwzględnieniem przywróconej pełnej podmiotowości i suwerenności Rzeczypospolitej i jej najważniejszych sąsiadów w regionie. Polska dyplomacja musiała określić priorytety i cele Rzeczypospolitej w jej stosunkach z innymi - w pełni już niepodległymi - państwami w Europie Środkowo-Wschodniej. Najważniejszymi zadaniami polskiej polityki zagranicznej w tym obszarze stały się: zdefiniowanie przyjacielskich i dobrosąsiedzkich relacji z Czechosłowacją (po 1993 r. Czechami i Słowacją), Węgrami oraz Rumunią w celu stabilizacji regionu; nawiązanie z nimi bliskiej współpracy politycznej i gospodarczej (bilateralnej i wielostronnej); wreszcie - ustalenie wzajemnego wsparcia i współpracy we wspólnym dążeniu do wejścia w skład Paktu Północnoatlantyckiego (traktowanego jako gwarant bezpieczeństwa) oraz Unii Europejskiej (postrzeganej jako klucz do rozwoju gospodarczego i dobrobytu).

Wspomniane wyżej zadania byly i są realizowane z powodzeniem. W $1991 \mathrm{r}$. podpisano układ o dobrym sąsiedztwie i współpracy z Czechosłowacją. Po jej podziale Polska natychmiast uznała Czechy i Słowację, które stały się sukcesorkami umów zawartych przez państwo czechosłowackie. Z kolei w $1993 \mathrm{r}$. Warszawa i Bukareszt zawarły układ o przyjaznych stosunkach. Do najlepszych w regionie należą również relacje polsko-węgierskie - w 2007 r. parlament węgierski ogłosił 23 marca Dniem Przyjaźni Polsko-Węgierskiej, natomiast polscy parlamentarzyści ustanowili rok 2016 Rokiem Solidarności Polsko-Węgierskiej.

W ramach umów wielostronnych już w 1991 r. Polska, Węgry i Czechosłowacja podjęły współpracę w ramach Grupy Wyszehradzkiej, celem zbliżenia tych krajów do polityczno-wojskowych i gospodarczych struktur euroatlantyckich. Zobowiązano się konsultować, koordynować i wspierać swoje działania na arenie międzynarodowej. Zadeklarowano też wspólnotę celów i zadań wewnętrznych - poszanowanie praw człowieka, budowanie demokracji parlamentarnej oraz reformowanie gospodarki w kierunku wolnorynkowym (po podziale Czechosłowacji zobowiązania te uznały - pomimo pewnych wahań - Czechy i Słowacja). W 1992 r. Warszawa, Praga, Bratysława i Budapeszt podpisały Środkowoeuropejskie Porozumienie o Wolnym Handlu. W 2000 r. powołały zaś do życia Międzynarodowy Fundusz Wyszehradzki.

W latach 1999-2004 zakończyly się sukcesem starania Polski, Czech, Słowacji, Węgier i Rumunii o przystąpienie do NATO i Unii Europejskiej. W 1999 r. Rzeczpospolita, Czechy, Węgry i Rumunia stały się członkami Paktu 
Północnoatlantyckiego. W 2004 r. dołączyły do nich Rumunia i Słowacja. W tym samym roku Warszawa, Praga, Bratysława, Budapeszt i Bukareszt sfinalizowały negocjacje o wstąpienie do UE. Natomiast w 2007 r. do Unii Europejskiej została przyjęta Rumunia. Państwa te, zarówno w ramach NATO, jak i UE, tworzą obecnie grupę ściśle współdziałających ze sobą partnerów, których specyfikę, a zarazem szczególną wspólnotę losu określa w pierwszym przypadku usytuowanie na tzw. wschodniej flance Paktu Północnoatlantyckiego, w drugim - próba budowy regionalnego polityczno-gospodarczego porozumienia określanego historycznym mianem Międzymorza (Trójmorza) ${ }^{15}$.

Warto przy tym zauważyć, że po 1989 r. bardzo żywe przekonanie o konieczności budowania regionalnych porozumień panowało wśród polskich elit politycznych. Postulaty takie stały się częścią programów licznych polskich partii. Opowiadała się za nim Konfederacja Polski Niepodległej, Ruch Trzeciej Rzeczypospolitej, czy obecnie Prawo i Sprawiedliwość. Także liczne stowarzyszenia spoleczne - m.in. Fundacja Wschodnia Wiedza, Towarzystwo Pomost, a także Stowarzyszenie Współpracy Narodów Europy Wschodniej Zbliżenie.

\section{Polskie koncepcje ładu w Europie Środkowo-Wschodniej w XX wieku}

Ambicje organizowania ładu środkowoeuropejskiego z udziałem Polaków pojawily się $\mathrm{w}$ polskiej refleksji politycznej jeszcze przed wybuchem I wojny światowej i odrodzeniem niepodległej Rzeczypospolitej. Ich wyrazicielem był m.in. twórca, przywódca i ideolog polskiego obozu narodowego, Roman Dmowski. Jako platformę do głoszenia hasła współpracy słowiańskich narodów regionu pragnął on wykorzystać tzw. ruch neosłowiański. Jego partnerem $\mathrm{w}$ próbach realizacji w tym kontekście zbliżenia polsko-czeskiego okazał się narodowo-konserwatywny polityk czeski Karel Kramár.

Bliskim współpracownikiem R. Dmowskiego, wspierającym jego koncepcje zorganizowania ruchu neosłowiańskiego, był m.in. jeden z liderów obozu narodowego Stanisław Kozicki, który wskazywał, że ruch ten może stanowić instrument w negocjacjach z Petersburgiem, dotyczących realizacji narodowych ambicji Polaków ${ }^{16}$. Warto dodać, iż tymczasowe - jak się okazało - zaangażowanie polskich narodowców w ruch neosłowiański i współpracę z Czechami

15 T. Szymczyński (2009): Negocjowanie granic: od „UE-15” do „UE-27”. Rozszerzenie wschodnie Unii Europejskiej, cz. 1, „Grupa Luksemburska” (2004) - Estonia, Polska, Republika Czeska, Stowenia, Węry, Cypr w UE, Poznań.

16 S. Kozicki (2009): Pamiętnik 1876-1939, oprac. M. Mroczko, Słupsk, s. 240. 
chcieli oni wykorzystać do rozszerzenia porozumienia na rumuńskie środowiska polityczne.

W latach międzywojennych stosunek polskich myślicieli politycznych, polityków i publicystów do państw Europy Środkowo-Wschodniej - przede wszystkim Czechosłowacji, Węgier i Rumunii - i idei szerszego regionalnego porozumienia, był zróżnicowany.

Wobec Czechosłowacji Józef Piłsudski (w latach 1918-1922 Naczelnik Państwa, a od 1926 r. dyktator) oraz jego adherenci byli nastawieni sceptycznie. Wskazywali oni na słabość tego wielonarodowego państwa, jego antypolską politykę wspierania ukraińskiej irredenty w Rzeczypospolitej, konkurowanie z Warszawą o miano gwaranta bezpieczeństwa regionu i bliskie relacje ze Związkiem Sowieckim.

Stanowisko to podzielali zasadniczo międzywojenni socjaliści, rewidując je dopiero $\mathrm{w}$ drugiej połowie lat trzydziestych przez uznanie wartości Czechosłowacji jako istotnego gwaranta ładu powersalskiego. Tymczasem politycy obozu narodowego, m.in. wspomniany już S. Kozicki, konsekwentnie opowiadali się za bliską wspólpracą z Pragą na gruncie wspólnego przeciwstawiania się niemieckiemu rewizjonizmowi.

Niejednoznaczna była także postawa polskich polityków i komentatorów sytuacji międzynarodowej wobec Węgier. W publicystyce reprezentującej stanowisko wszystkich znaczących obozów politycznych - od piłsudczyków i socjalistów, aż po narodowców - wdzięczność dla Budapesztu za gotowość do niesienia pomocy Rzeczypospolitej w okresie sowieckiej inwazji 1920 r. mieszała się z rezerwą wobec państwa, które kontestowało ład wersalski i było niechętne strategicznemu sojusznikowi Polski - Rumunii.

$\mathrm{W}$ drugiej połowie lat trzydziestych w związku z koncepcją ówczesnego ministra spraw zagranicznych J. Becka budowy systemu Międzymorza, obejmującego w najbardziej ambitnym wydaniu nie tylko Rzeczpospolitą, Węgry i Rumunię, ale również Jugosławię (zakładającego także ścisłe powiązania z Włochami), nastąpił w polityce obozu rządzącego zwrot w kierunku jednoznacznie pozytywnej oceny polityki i roli Budapesztu. Konsekwentnie sprzyjające Madziarom stanowisko zajmowali myśliciele polityczni, wywodzący się z kręgów konserwatywnych - Marian Zdziechowski, Jan Dąbrowski i Władysław Studnicki, uznawani przy tym powszechnie za znawców problematyki węgierskiej ${ }^{17}$.

Do bliskich związków politycznych, gospodarczych i wojskowych z trzecim z południowych sąsiadów Polski - Rumunią - entuzjastycznie nastawieni

17 Hr. Bem de Cosban (1936): Polsko-węgierska wspólna granica, Cieszyn, s. 13. 
byli piłsudczycy. Rolę Bukaresztu jako sojusznika podkreślała także publicystyka obozu narodowego.

W latach II wojny światowej zagadnienie stworzenia po jej zakończeniu sieci ścisłych politycznych, wojskowych i gospodarczych porozumień pomiędzy Rzecząpospolitą a jej południowymi sąsiadami było przedmiotem refleksji zarówno polityków i publicystów sprzyjających premierowi Władysławowi Sikorskiemu i jego gabinetowi, jak i myślicieli politycznych związanych z opozycyjnym wobec generała obozem piłsudczykowskim.

Jednak sikorszczycy skupiali się przede wszystkim na ograniczonej koncepcji budowy konfederacji lub federacji polsko-czechosłowackiej, wskazując na teoretyczny charakter podobnych rozważań odnoszących się do Budapesztu i Bukaresztu, pozostających we wrogim obozie państw Osi.

Tymczasem sanatorzy - zarówno na emigracji, jak i w okupowanym kraju - wybiegając w przyszłość, planowali zbudowanie w regionie Europy Środkowo-Wschodniej silnej wielopaństwowej federacji z udziałem Węgier i Rumunii. Czołowym wyrazicielem tej koncepcji był Ignacy Matuszewski ${ }^{18}$. Myśl tę rozwijali również po zakończeniu II wojny światowej, obejmując w granicach przewidywanej federacji (bądź dwóch współpracujących ze sobą federacji) państwa Europy Środkowej i Wschodniej od Skandynawii, przez Nadbałtykę, Białoruś i Ukrainę, aż po Bałkany.

Koncepcje te znalazły kontynuatorów w niepodległej III Rzeczypospolitej zwłaszcza w środowisku politycznym Konfederacji Polski Niepodległej (Leszek Moczulski) oraz wśród eksperckiego zaplecza Prawa i Sprawiedliwości.

W XX i XXI stuleciu narody i państwa Europy Środkowo-Wschodniej - Czesi, Słowacy, Węgrzy i Rumuni oraz państwo węgierskie, rumuńskie i czechosłowackie (czeskie i słowackie) - były przedmiotem szczególnej uwagi polskiej dyplomacji, polityków i publicystów. Początkowo - do 1918 r., istotnego ze względu na zakończenie I wojny światowej, klęskę państw centralnych i rozpad Austro-Węgier - zainteresowanie to generowały sprzeczne wizje południowych sąsiadów, zamieszkujących pomiędzy Karpatami, Morzem Czarnym i dorzeczem Dunaju, zarazem jako potencjalnych sprzymierzeńców sprawy polskiej i sojuszników w walce z dualistyczną monarchią Habsburgów o suwerenność i pozycję w Europie, jak i konkurentów Polaków w rywalizacji o zdobycie uprzywilejowanego stanowiska w ramach austro-węgierskiego państwa.

Dwudziestolecie międzywojenne przyniosło wynikające $\mathrm{z}$ oczywistej potrzeby próby budowania dobrych, czy wręcz sojuszniczych relacji pomiędzy

${ }^{18}$ I. Matuszewski (1942): O co walczymy?, New York, s. 5-6. 
niepodległą Rzecząpospolitą i jej sąsiadami - niepodległą Rumunią, Węgrami i Czechosłowacją. O ile w przypadku Bukaresztu i Budapesztu zakończyły się one powodzeniem, o tyle wysiłki te w odniesieniu do Pragi - rywalki Warszawy w staraniach o uzyskanie statusu najważniejszego państwa regionu i najpoważniejszego sojusznika Francji na wschodzie Starego Kontynentu, odmiennie diagnozującej ewentualne zagrożenie ze strony Rosji Sowieckiej (później Związku Sowieckiego), pozostającej z nią przy tym w sporze granicznym o Śląsk Cieszyński - spaliły na panewce. Nie powiodły się również plany polskiej dyplomacji - ambitne, aczkolwiek, jak się okazało, nierealne wobec regionalnych konfliktów interesów, braku wystarczającego potencjału Rzeczypospolitej i agresywnych działań III Rzeszy - ustabilizowania Europy Środkowo-Wschodniej przez utworzenie tzw. Międzymorza, czyli polityczno-wojskowo-gospodarczego związku państw sąsiadujących ze sobą pomiędzy Bałtykiem, Dunajem i Morzem Czarnym.

W latach II wojny światowej relacje pomiędzy narodami Europy Środkowo-Wschodniej uległy jeszcze większym komplikacjom. Nacje te znalazły się w dwóch wrogich obozach. II Rzeczpospolita (od 1939 r. jej zachodnie ziemie, a od 1941 r. całe terytorium), podobnie jak zachodnie obszary Czechosłowacji (Czechy i Morawy) znajdowały się pod okupacją niemiecką. Walkę z III Rzeszą w szeregach koalicji antyhitlerowskiej kontynuowały władze i podporządkowane im siły zbrojne obydwu państw, odbudowane na emigracji. Jednak próby nawiązania bliższej wspólpracy i stworzenia podwalin pod powojenną konfederację Rzeczypospolitej i Czechosłowacji, podejmowane przez rządy obydwu państw na uchodźstwie, zakończyły się niepowodzeniem. Natomiast Słowacja (formalnie niepodległa od 1939 r.), Węgry (niezależnie od sympatii, jaką ich obywatele - z wzajemnością - darzyli Polaków) i Rumunia stały się satelitami Niemiec, wspierającymi ich na froncie wschodnim.

Zakończenie wojny i przejęcie przez Związek Sowiecki pełnej kontroli nad Europą Środkowo-Wschodnią oznaczało dla Polski, na powrót zjednoczonej Czechosłowacji, Węgier i Rumunii skomunizowanie oraz utratę rzeczywistej suwerenności. Uniemożliwiało też podmiotowe kształtowanie przez Polskę relacji z sąsiadami $w$ regionie. $W$ ramach tzw. bloku wschodniego Warszawa, Praga, Budapeszt i Bukareszt na cztery i pół dekady znalazły się w polityczno-wojskowym sojuszu (Układ Warszawski) i gospodarczym związku (Rada Wzajemnej Pomocy Gospodarczej), których hegemonem pozostawał czerwony Kreml. Tego stanu rzeczy nie były w stanie zmienić dramatyczne w swym przebiegu wystąpienia Polaków, Czechów, Słowaków i Węgrów przeciwko komunistycznej dyktaturze i zniewoleniu przez ZSRS.

Gospodarcze i ideologiczne bankructwo komunizmu, upadek i rozpad Związku Sowieckiego oraz będące ich konsekwencją rozwiązanie UW i RWPG 
w początku ostatniej dekady minionego stulecia, przywróciło krajom Europy Środkowo-Wschodniej suwerenność i otworzyło przed Warszawą perspektywy odbudowy autentycznych relacji z Pragą (po podziale Czechosłowacji na Czechy i Słowację - również z Bratysławą), Budapesztem i Bukaresztem, opartych na realizacji rzeczywistych państwowych i narodowych interesów. Ustanawiały one przyjazne stosunki i wzajemne wsparcie starań o przyjęcie w skład Paktu Pólnocnoatlantyckiego i Unii Europejskiej. Po osiągnięciu tych celów wspólnotę interesów Polski, Czech, Słowacji, Węgier i Rumunii określa ich funkcjonowanie jako wschodniej flanki NATO oraz nowych członków UE - tzw. młodej Unii. W drugiej dekadzie XXI w. nowym czynnikiem, który może stanowić w przyszłości o zacieśnieniu politycznej i gospodarczej współpracy Warszawy z Pragą, Bratysławą, Budapesztem i Bukaresztem, stał się nowy projekt Międzymorza, formułowany najwyraźniej przez polską dyplomację, oparty na przesłankach ekonomicznych (zwłaszcza w dziedzinie energetyki) i wspierany przez Stany Zjednoczone - filar NATO oraz partnera gospodarczego UE. 